\footnotetext{
JURNAL CEMERLANG: Pengabdian pada Masyarakat

P-ISSN 2654-4741 / E-ISSN 2655-7894

Vol. 4, No. 1, Desember 2021, 76 - 87

DOI: https://doi.org/10.31540/jpm.v4i1.1397

PENERBIT: LP4MK STKIP PGRI LUBUKLINGGAU
}

\title{
SOSIALISASI PEMANFAATAN LIMBAH TANAMAN BUNCIS (PHASEOLUS VULGARIS, L) SEBAGAI PUPUK CAIR DI DESA TONGKOK
}

\author{
Endang Lovisia ${ }^{1}$, Merti Triyanti ${ }^{2}$ \\ ${ }^{1}$ Program Studi Pendidikan Fisika, STKIP PGRI Lubuklinggau \\ ${ }^{2}$ Program Studi Pendidikan Biologi, STKIP PGRI Lubuklinggau \\ Jalan Mayor Toha Kelurahan Air Kuti, Kota Lubuklinggau, 31628, Indonesia \\ Email: mertitriyanti28@gmail.com
}

\begin{abstract}
ABSTRAK
Kegiatan pengabdian kepada masyarakat ini dilatarbelakangi oleh banyaknya limbah tanaman buncis di Desa Tongkok Kabupaten Lahat yang belum dimanfaatkan secara optimal terutama sebagai pupuk cair. Limbah dari tanaman buncis tersebut dibuang, dibakar dan tidak digunakan. Hal ini menyebabkan tingginya volume sampah dan pencemaran lingkungan. Oleh karena itu, tim PKM STKIP PGRI lubuklinggau mencoba mensosialisasikan pemanfaatan limbah tanaman buncis (Phaseolus Vulgaris, $L$ ) sebagai pupuk cair di desa tongkok. PKM ini telah dilakukan dengan melibatkan mitra yaitu masyarakat desa Tongkok dan diikuti dengan antusias. Target keluaran yang ingin dicapai oleh tim PKM adalah peningkatan nilai masyarakat dan publikasi. Dalam pelaksanaannya menggunakan metode teoritis dan praktis mulai dari tahap persiapan, pemberian materi dan praktek pembuatan pupuk cair limbah tanaman buncis.
\end{abstract}

ABSTRACK

This community service activity is motivated by the large amount of waste from bean plants in Tongkok Village, Lahat Regency which has not been used optimally, especially as liquid fertilizer. Waste from the bean plant is disposed of, burned and not used. This causes a high volume of waste and environmental pollution. Therefore, the pkm stkip pgri lubuklinggau team tried to socialize the use of bean plant waste (Phaseolus Vulgaris, L) as liquid fertilizer in tongkok village. This PKM has been carried out by involving partners, namely the Tongkok village community and is enthusiastically followed. The output target to be achieved by the PKM team is to increase community values and publications. In its implementation, it uses theoretical and practical methods starting from the preparation stage, providing materials and practices for making liquid fertilizer for bean plant waste

KEYWORDS

Sosialisasi, Pupuk Cair, Tanaman Buncis

socialization, liquid fertilizer, green beans

\section{ARTICLE HISTORY}

Received 19 Oktober 2021

Revised 25 November 2021

Accepted 16 Desember 2021

CORRESPONDENCE Merti Triyanti@ mertitriyanti28@gmail.com 


\section{JURNAL CEMERLANG: Pengabdian pada Masyarakat \\ P-ISSN 2654-4741 / E-ISSN 2655-7894 \\ Vol. 4, No. 1, Desember 2021, 76 - 87 \\ DOI: https://doi.org/10.31540/jpm.v4i1.1397 \\ PENERBIT: LP4MK STKIP PGRI LUBUKLINGGAU}

\section{PENDAHULUAN}

Sektor pertanian merupakan sektor yang paling penting di Indonesia sehingga dijadikan sebagai fondasi dalam pembangunan. Salah satu subsektor pertanian yang memiliki peranan penting dalam menunjang pembangunan dan perekonomian nasional adalah sub sektor hortikultura. Hal ini didukung oleh karakteristik lahan dan agroklimat serta sebaran wilayah yang luas memungkinkan wilayah Indonesia sebagai daerah pertanian yang sangat berpotensial untuk mengembangkan komoditas hortikultura (Fajriah dkk, 2018).

Tanaman buncis merupakan salah satu tanaman hortikultura yang dikenal yang banyak dikonsumsi masyarakat Indonesia. Produksi buncis di Indonesia mengalami kenaikan dari tahun ke tahun antara lain pada tahun 2016 produksi sebesar 275. 152 ton dan pada tahun 2017 sebesar 279.041 ton (Dirjen Hortikultura, 2018). Tanaman buncis buncis termasuk jenis sayuran polong semusim (berumur pendek). Menurut Djuariah (2016) tanaman buncis memiliki 2 tipe yakni tipe tegak dan tipe merambat. Tinggi tanaman buncis tegak berkisar antara $30-50 \mathrm{~cm}$. Sedangkan tinggi tanaman buncis tipe merambat dapat mencapai $2 \mathrm{~m}$. Tanaman kacang buncis biasanya dikonsumsi dalam bentuk polong segar, biji kering, kecambah, maupun daun mudanya bahkan juga dikonsumsi untuk sayuran hijau dan banyak diminati oleh masyarakat.

Tanaman buncis (Phaseolus vulgaris L.) merupakan tanaman semusim yang berbentuk perdu. Buncis merupakan tanaman yang berasal dari Meksiko Selatan dan Amerika Tengah, bukan asli Indonesia. Kemudian tanaman ini menyebar ke berbagai negara. Pada mulanya, hanya dikenal beberapa jenis buncis saja. Namun, dengan berkembangnya ilmu pengetahuan dan teknologi, kini telah banyak ditemukan jenis-jenis atau varietas tanaman buncis yang lebih baik (Cahyono, 2013). Sedangkan menurut Rihana dkk (2013) tanaman buncis merupakan salah satu sayuran kelompok kacang-kacangan yang digemari masyarakat karena merupakan salah satu sumber protein nabati dan kaya akan vitamin A, B dan C. 


\section{JURNAL CEMERLANG: Pengabdian pada Masyarakat \\ P-ISSN 2654-4741 / E-ISSN 2655-7894 \\ Vol. 4, No. 1, Desember 2021, 76 - 87 \\ DOI: https://doi.org/10.31540/jpm.v4i1.1397 \\ PENERBIT: LP4MK STKIP PGRI LUBUKLINGGAU}

Tanaman buncis pun dapat dikonsumsi dalam bentuk sayuran hijau, selain itu beberapa jenis tertentu dapat dikonsumsi dalam bentuk biji.

Untuk memperoleh hasil yang maksimal dari tanaman buncis, petani menggunakan pupuk pada saat penanaman buncis, hal ini dapat dikatakan bahwa pengaruh pupuk terhadap pertumbuhan suatu tanaman memegang peranan yang sangat penting. Akhir-akhir ini, pupuk anorganik semakin banyak digunakan. Hampir semua petani menggunakan pupuk kimia seperti Urea, Za, dan KCL, sebagai nutrisi untuk tanaman dalam kegiatan pertanian maupun perkebunan mereka. Penggunaan ini tentunya berdasar pada keunggulan penggunaan pupuk kimia yang memiliki pengaruh antara lain pemberiannya dapat terukur dengan tepat, kebutuhan tanaman akan hara dapat dipenuhi dengan perbandingan yang tepat dan dalam waktu yang cepat, kadar unsur yang dikandungnya tinggi, sehingga dengan pemberian yang sedikit dapat memenuhi kebutuhan tanaman, banyak diperjual bellikan sehingga mudah didapat, proses pengangkutan ke lahan lebih mudah karena jumlah yang diangkut lebih sedikit, dan cepat diserap oleh tanaman. Hal yang diharapkan oleh para petani dalam penggunaannya, pupuk kimia mampu memberikan hasil yang optimal dan sebuah keuntungandari segi ekonomi bagi para petani.

Ketergantungan ini semakin tinggi setelah adanya subsidi harga dari pemerintah, yang membuat pupuk sedikit lebih murah dan mudah didapatkan oleh para petani. Hampir setiap musim panen petani membeli pupuk bersubsidi. Hal ini menunjukkan bahwa dalam melakukan aktifitas bercocok tanamnya para petani lebih cenderung menggunakan pupuk kimia, karena dianggap pengunaan pupuk ini lebih praktis walaupun harga pupuk ini sedikit mahal. Hitungan biaya kebutuhan pupuk setiap musim panen yang juga disajikan pada penelitian tersebut mencapai 550 ribu rupiah.

Namun demikian, seperti yang dinyatakan oleh Abdullah (2015) dalam penelitiannya, penggunaan pupuk anorganik saja secara terus menerus dapat menyebabkan ketidakseimbangan hara dalam tanah, bahkan dapat menimbulkan 


\section{JURNAL CEMERLANG: Pengabdian pada Masyarakat \\ P-ISSN 2654-4741 / E-ISSN 2655-7894 \\ Vol. 4, No. 1, Desember 2021, 76 - 87 \\ DOI: https://doi.org/10.31540/jpm.v4i1.1397 \\ PENERBIT: LP4MK STKIP PGRI LUBUKLINGGAU}

masalah sosial, ekonomi, meningkatnya biaya produksi, menurunnya kualitas hasil pertanian dan menurunnya kualitas lingkungan akibat polusi air, tanah, dan udara. Penggunaan input kimiawi dengan dosis tinggi tidak saja berpengaruh menurunkan tingkat kesuburan tanah, tetapi juga berakibat pada merosotnya keragaman hayati dan meningkatnya serangan hama, penyakit dan gulma. Dampak negatif lain yang dapat ditimbulkan oleh pertanian anorganik adalah tercemarnya produk-produk pertanian oleh bahan kimia yang selanjutnya akan berdampak buruk terhadap kesehatan.

Berdasarkan permasalahan tersebut, maka perlu sebuah solusi untuk mengurangi ketergantungan para petani terhadap penggunaan pupuk anorganik dengan mensubstitusinya menggunakan pupuk organik. Pupuk organik yang selama ini telah digunakan meliputi pupuk kandang, pupuk kompos, dan pupuk organik cair membuktikan memiliki daya dukung yang baik dalam mengembalikan kesuburan tanah. Seperti yang dikatakan oleh Sutanto (2012), hal ini disebabkan karena pupuk organik dapat meningkatkan efisiensi penggunaan pupuk dan daya mengikat air serta mengaktifkan mikro organisme tanah. Dengan adanya perbaikan sifat fisik, kimia dan biologi tanah maka kesuburan tanah juga akan meningkat.

Tongkok merupakan desa bagian dari Kabupaten Lahat berbatasan langsung dengan Kota Pagar Alam Provinsi Sumatera Selatan yang mayoritas penduduk disekitar tempat ini memiliki mata pencarian $75 \%$ sebagai petani yang hanya mengandalkan tanaman sayuran, padi dan kopi. Petani sayuran mayoritas menanam tanaman buncis, hal ini menyebabkan membludaknya tanaman tersebut sehingga sampah dari tanaman tersebut pun semakin banyak baik dari sisa tanaman maupun dari bagian tanaman buncis yang busuk dari segi buah dan daun. Bedasarkan hasil observasi yang dilakukan oleh TIM diperoleh informasi bahwa sampah tanaman buncis hanya dibakar atau dihanyutkan disungai sekitar areal pertanian saja. Belum diolah sama sekali menjadi pupuk cair, mengingat 


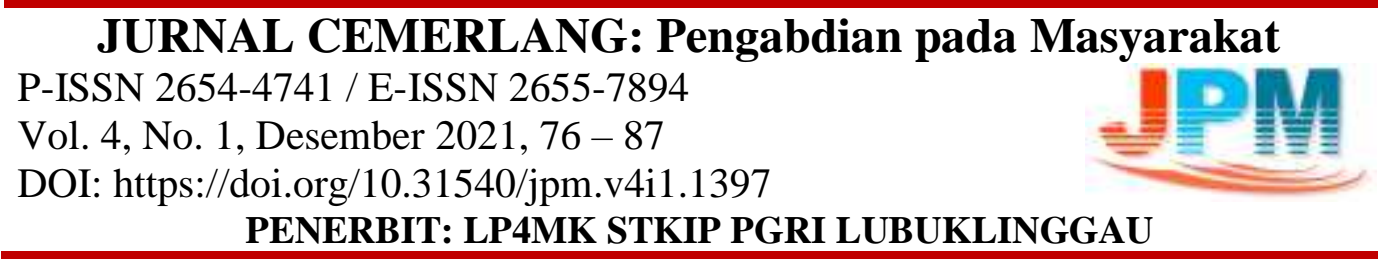

minimnya pengetahuan masyarakat. Salah satu penanganan sampah organik yang efektif adalah mengolahnya sebagai pupuk organik (Yuwono, 2014).
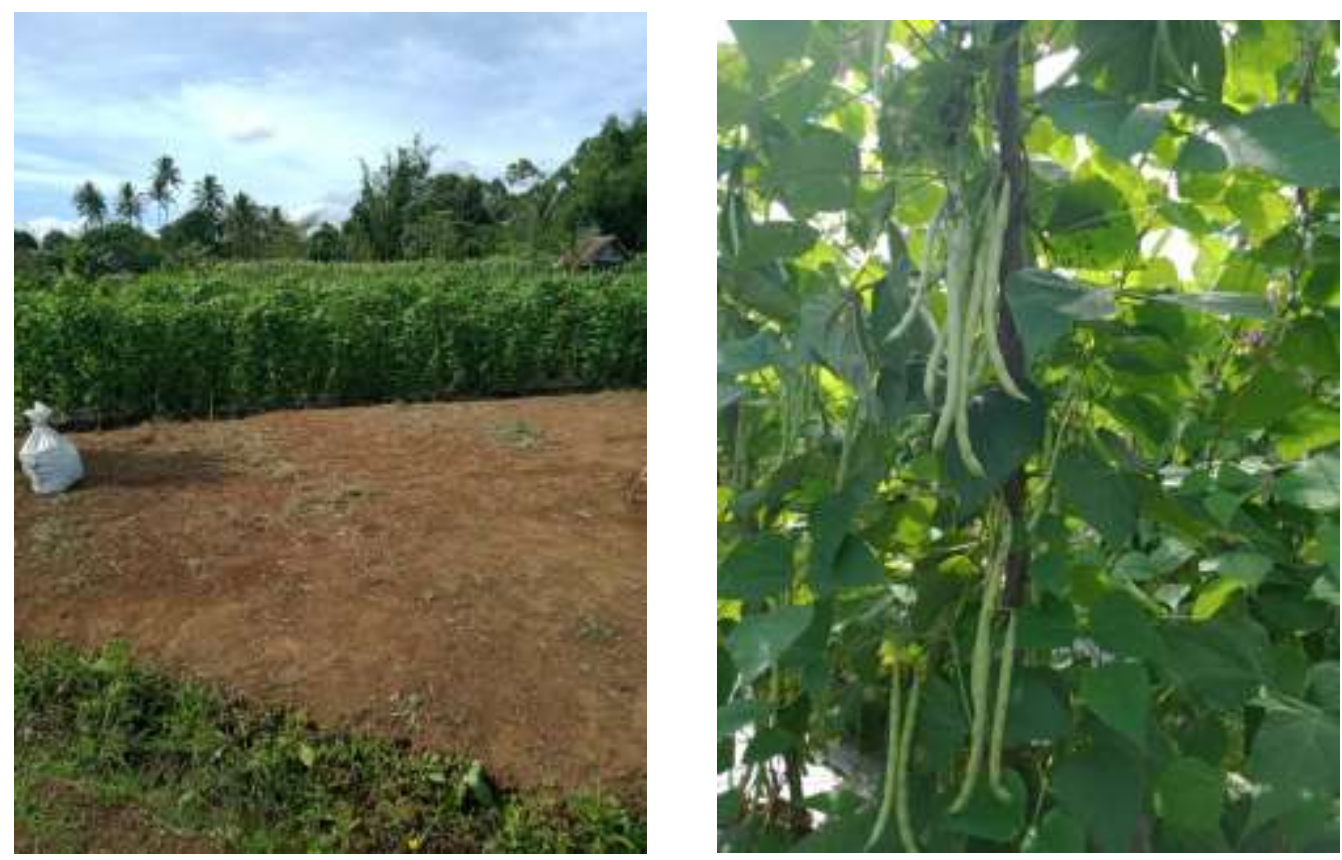

Gambar 1. Perkebunan Tanaman Buncis

Dengan adanya ketergantungan masyarakat Desa Tongkok khususnya kelompok tani pada pupuk anorganik yang relatif mahal dan dalam penggunaan berkelanjutan dapat merusak kesuburan tanah serta tidak baik untuk kesehatan, padahal jenis sampah organik berupa limbah buncis sangat banyak dan menumpuk, tetapi pengetahuan pengolahan sisa tanaman buncis yang masih sangat minim maka TIM Pengabdian Kepada Masyarakat mempunyai alternatif untuk membantu warga di Desa Binaan dengan memanfaatkan sisa sampah diatas menjadi pupuk cair yang nantinya berguna bagi masyarakat di Desa Tongkok.

\section{METODE}

Peserta kegiatan Pengabdian kepada masyarakat ini adalah masyarakat Desa Tongkok pada umumnya dan kelompok tani pada khususnya, pelaksanaan PKM ini dimulai pada pekan ke empat bulan april sampai dengan pekan pertama bulan Mei 2021 yang diikuti oleh peseta sebanyak 20 orang. Mengingat situasi 


\section{JURNAL CEMERLANG: Pengabdian pada Masyarakat \\ P-ISSN 2654-4741 / E-ISSN 2655-7894 \\ Vol. 4, No. 1, Desember 2021, 76 - 87 \\ DOI: https://doi.org/10.31540/jpm.v4i1.1397 \\ PENERBIT: LP4MK STKIP PGRI LUBUKLINGGAU}

saat ini masih dalam keadaan pandemi COVID-19 maka jumlah peserta dibatasi oleh perangkat desa dan pada saat pelaksanaan PKM ini menerapkan protokol kesehatan yaitu menyediakan tempat cuci tangan, memakai masker dan menjaga jarak. Adapun tahapan yang kami laksanakan yaitu:

1. Langkah pertama adalah melakukan survey ke lokasi Desa Tongkok

2. Langkah kedua adalah melakukan penyuluhan atau sosialisasi. Kelompok Tani diberikan pengetahuan atau wawasan mengenai pengetahuan jenis sampah organik, cara memilah sampah organik dan membuat sampah organik menjadi pupuk cair. Penyuluhan atau sosialisasi dilaksanakan dengan presentasi dan diskusi yang bertujuan untuk memberikan wawasan dan pengetahuan kepada kelompok tani.

3. Langkah ketiga adalah Pelatihan pembuatan pupuk cair dari bahan organik berupa limbah tanaman buncis. Pada tahap ini kelompok tani akan dilatih untuk dapat membuat pupuk cair yang berbahan limbah tanaman buncis. Selama pelatihan akan dilakukan kegiatan pembimbingan dan konsultasi

4. Langkah keempat adalah monitoring dan pendampingan. Pada tahap ini untuk memastikan pupuk cair yang dibuat berhasil maka dilakukan pendampingan secara berkala.

Adapun bahan dan alat yang digunakan pada saat pembuatan pupuk organik cair adalah: Sampah organik basah, yaitu sisa dari tanaman buncis yang sudah tidak bisa digunakan lagi seperti daun, buah yang busuk, dan tangkai/batang buncis kemudian dirajang/dipotong kecil-kecil.

1. Karung beras/goni, sehingga air dapat meresap ke dalam pori-pori karung tersebut dan bahan dalam karung tidak bisa keluar.

2. Cairan molase dapat diganti dengan gula putih/perasan air tebu atau gula merah (dalam hal ini TIM menggunakan gula merah, karena mudah didapatkan), kemudian dilarutkan dengan air yang akan digunakan sebagai larutan media

3. EM4 sebanyak 1 liter 


\section{JURNAL CEMERLANG: Pengabdian pada Masyarakat \\ P-ISSN 2654-4741 / E-ISSN 2655-7894 \\ Vol. 4, No. 1, Desember 2021, 76 - 87 \\ DOI: https://doi.org/10.31540/jpm.v4i1.1397 \\ PENERBIT: LP4MK STKIP PGRI LUBUKLINGGAU}

4. Ember/tong plastik/bahan lain lengkap dengan tutup dan kapasitas sekitar 120 liter untuk membuat pupuk cair.

5. Tali untuk mengikat ujung karung sehingga bahan dalam karung tidak bisa keluar.

6. Batu untuk pemberat, supaya karung dapat tenggelam.

7. Penutup drum/plastik hitam atau tutup lain, supaya sinar matahari maupun air hujan tidak dapat masuk ke dalam drum/wadah.

Cara pembuatan pupuk organik cair adalah:

1. Isi karung dengan limbah tanaman buncis yang sudah disiapkan (yang telah dicincang halus) kemudian tambahkan EM4 dan lautan molase (gula merah) tutup rapat-rapat agar udara tidak masuk (anaerob) lalu ikat karungnya.

2. Masukan karung berisi limbah tanaman buncis tersebut ke dalam drum kosong / ember, kemudian diisi air. Perbandingan antara air dengan berat isi karung adalah 2 liter air untuk $1 \mathrm{~kg}$ berat isi karung.

3. Letakkan batu yang cukup berat di atas karung, sehingga karung tersebut dapat tenggelam. Drum dijaga selalu tertutup, agar tidak ada unsur hara yang hilang akibat penguapan.

4. Penyimpanan wadah harus ditempat yang teduh yang tidak tersinari oleh matahari

5. Tunggu sekitar 14 hari atau lebih, jika setelah waktu tersebut kita lihat ada bercak atau selaput putih pada permukaan larutan media, berarti proses fermentasi telah berhasil dan pupuk organik cair siap untuk dipanen. Sampah yang didalam karung bisa digunakan sebagai kompos dan cairannya sebagai pupuk organik cair.

\section{HASIL dan PEMBAHASAN}

Kegiatan PKM ini diikuti dengan antusia oleh warga di Desa Tongkok. Pupuk organik cair merupakan salah satu jenis pupuk yang banyak beredar di pasaran. Pupuk organik cair kebanyakan diaplikasikan melalui daun atau disebut 


\section{JURNAL CEMERLANG: Pengabdian pada Masyarakat \\ P-ISSN 2654-4741 / E-ISSN 2655-7894 \\ Vol. 4, No. 1, Desember 2021, 76 - 87 \\ DOI: https://doi.org/10.31540/jpm.v4i1.1397 \\ PENERBIT: LP4MK STKIP PGRI LUBUKLINGGAU}

sebagai pupuk cair foliar yang mengandung hara makro dan mikro esensial $(\mathrm{N}, \mathrm{P}$, $\mathrm{K}, \mathrm{S}, \mathrm{Ca}, \mathrm{Mg}, \mathrm{B}, \mathrm{Mo}, \mathrm{Cu}, \mathrm{Fe}, \mathrm{Mn}$, dan bahan organik). Pupuk organik cair selain dapat memperbaiki sifat fisik, kimia, dan biologi tanah, juga membantu meningkatkan produksi tanaman, meningkatkan kualitas produk tanaman, mengurangi penggunaan pupuk anorganik dan sebagai alternatif pengganti pupuk kandang (Parman, 2017). Pupuk organik cair merupakan hasil dari fermentasi. Proses fermentasi merupakan perubahan enzimatis secara anaerob dari senyawa organik dan menjadi produk organik ayng lebih sederhana. Hal ini merupakan pemanfaatan dari bioteknologi dalam pengelolaan limbah dan lingkungan. Pupuk organik cair mempunyai beberapa manfaat diantaranya adalah (Nur Fitri, Erlina Ambarwati, dan Nasih Widya, 2011) :

1. Dapat mendorong dan meningkatkan pembentukan klorofil daun dan pembentukan bintil akar pada tanaman leguminosae sehingga meningkatkan kemampuan fotosintesis tanaman dan penyerapan nitrogen dari udara.

2. Dapat meningkatkan vigor tanaman sehingga tanaman menjadi kokoh dan kuat, meningkatkan daya tahan tanaman terhadap kekeringan, cekaman cuaca dan serangan patogen penyebab penyakit.

3. Merangsang pertumbuhan cabang produksi.

4. Meningkatkan pembentukan bunga dan bakal buah, serta

5. Mengurangi gugurnya daun, bunga dan bakal buah.

Pupuk cair mengandung unsur hara makro dan mikro, dimana unsur hara mikro berfungsi sebagai activator sistem enzim atau dalam proses pertumbuhan tanaman, seperti fotosintesis dan respirasi. Begitu juga dengan kandungan hara makro yang cukup tersedia bagi kebutuhan tanaman, dapat meningkatkan panjang malai serta mampu meningkatkan hasil tanaman (Sitompul et al., 2014).

Pupuk organik cair mempunyai beberapa manfaat, diantaranya dapat mendorong dan meningkatkan pembentukan klorofil daun, dan pembentukan bintil akar pada tanaman leguminosae, sehingga meningkatkan kemampuan 


\section{JURNAL CEMERLANG: Pengabdian pada Masyarakat \\ P-ISSN 2654-4741 / E-ISSN 2655-7894 \\ Vol. 4, No. 1, Desember 2021, 76 - 87 \\ DOI: https://doi.org/10.31540/jpm.v4i1.1397 \\ PENERBIT: LP4MK STKIP PGRI LUBUKLINGGAU}

fotosintesis tanaman dan penyerapan nitrogen dari udara, dapat meningkatkan vigor tanaman sehingga tanaman menjadi kokoh dan kuat, meningkatkan daya tahan tanaman terhadap kekeringan, cekaman cuaca dan serangan patogen penyebab penyakit, merangsang pertumbuhan cabang produksi, sertam eningkatkan pembentukan bunga dan bakal buah, serta mengurangi gugurnya daun, bunga dan bakal buah.

Pembuatan pupuk organik cair dilakukan melalui proses fermentasi anaerob. Fermentasi dapat terjadi karena adanya aktivitas mikroorganisme penyebab fermentasi yang dapat menyebabkan perubahan sifat senyawa organik. Dalam proses fermentasi dibutuhkan mikroorganisme yang berfungsi untuk mempercepat proses fermentasi (Listiyana, 2016). Pupuk organik cair memiliki keuntungan karena tidak merusak tanah dan tanaman walaupun digunakan sesering mungkin. Selain itu, POC memiliki bahan pengikat, sehingga larutan pupuk yamg diberikan ke permukaan tanah bisa langsung digunakan oleh tanaman.

Kelebihan dari pupuk organik cair adalah dapat secara cepat mengatasi defensiesi hara, tidak masalah dalam pencucian hara, dan mampu menyediakan hara secara cepat. Dapat dikatakan bahwa pupuk organik cair merupakan salah satu bahan yang sangat penting dalam upaya memperbaiki kesuburan tanah. Hadisuwito (2012). POC dapat meningkatkan aktivitas kimia, biologi, dan fisik tanah sehingga tanah menjadi subur dan baik untuk pertumbuhan tanaman (Juarsah,2014). Peranan pupuk organik terhadap sifat biologi tanah adalah sebagai sumber energi dan makanan bagi mikro dan makro tanah. Kebutuhan unsur hara di dalam tanah dapat dilakukan dengan cara pemberian pupuk organik (Handayani, 2015).

Manfaat Pupuk Organik Cair diantaranya dapat mendorong dan meningkatkan pembentukan klorofil daun dan pembentukan bintil akar pada tanaman sehingga meningkatkan kemampuan fotosintesis tanaman dan penyerapan nitrogen dari udara, dapat meningkatkan vigor tanaman sehingga tanaman menjadi kokoh dan kuat, meningkatkan daya tahan tanaman terhadap 


\section{JURNAL CEMERLANG: Pengabdian pada Masyarakat \\ P-ISSN 2654-4741 / E-ISSN 2655-7894 \\ Vol. 4, No. 1, Desember 2021, 76 - 87 \\ DOI: https://doi.org/10.31540/jpm.v4i1.1397 \\ PENERBIT: LP4MK STKIP PGRI LUBUKLINGGAU}

kekeringan, cekaman cuaca dan serangan patogen penyebab penyakit, merangsang pertumbuhan cabang produksi, meningkatkan pembentukan bunga dan bakal buah, serta mengurangi gugurnya daun, bunga dan bakal buah.

Untuk memenuhi kebutuhan nutrisi akan tanaman buncis masyaakat Desa Tongkok masih sangat bergantung dengan pupuk anorganik, mengingat saat ini ada jenis pupuk anorganik yang di subsisdi oleh pemerintah. Padahal pupuk anoganik cair ini jika digunakan secara berkelanjutan bisa mengurangi unsur kesuburan tanah, serta tidak baik untuk kesehatan.

Berdasarkan kegiatan pengabdian kepada masyarakat yang telah dilaksanakan pada pekan ke empat bulan April sampai dengan pekan pertama bulan Mei 2021 dengan tahapan awal melakukan observasi ke masyarakat dengan memperhatikan dan mencari tahu bagaimana memberikan solusi kepada warga mengingat banyaknya limbah tanaman buncis yang ditumpuk serta mengatasi ketergantungan warga akan pupuk anorganik, selain itu bisa dijadikan sebagai usaha rumah tangga dengan cara memasarkan produk pupuk cair tersebut, sehingga TIM Dosen STKIP-PGRI Lubuklinggau membantu warga Desa Tongkok untuk membantu permasalah tersebut.

Dalam kegiatan yang telah dilaksanakan tersebut masyarakat Desa Tongkok diajarkan cara pembuatan alat dekomposter sederhana terbuat dari ember plastik yang hemat akan biaya dan bisa dijangkau oleh semua lapisan masyarakat serta cara pembuatan pupuk organik cair. Warga sangat antusias pada saat pelatihan pembuatan pupuk organik cair, praktek pembuatan pupuk organik cair, serta hasil uji coba dari proses pembuatan pupuk organik cair. Mereka beranggapan bahwa kedatangan TIM PKM ini sangat membantu pemasalahan yang mereka hadapi. Begitu pula dengan dosen dan mahasiswa dari STKIP PGRI Lubuklinggau dengan adanya pelatihan yang telah dilaksanakan dalam program PKM beranggapan bahwa ilmu yang mereka miliki telah ditransfer dan sangat berguna demi kelangsungan hidup masyarakat pada umumnya khususnya ilmu mengenai teknik atau cara pembuatan pupuk organik cair secara sederhana. 


\section{JURNAL CEMERLANG: Pengabdian pada Masyarakat \\ P-ISSN 2654-4741 / E-ISSN 2655-7894 \\ Vol. 4, No. 1, Desember 2021, 76 - 87 \\ DOI: https://doi.org/10.31540/jpm.v4i1.1397 \\ PENERBIT: LP4MK STKIP PGRI LUBUKLINGGAU}

\section{SIMPULAN}

1. Masarakat desa Tongkok sudah mengetahui dan memahami mengenai jenis sampah yang terdiri dari sampah organik dan anorganik

2. Kelompok tani saat ini sudah dapat mengetahui dan melakukan memilah sampah dengan 3R. Reduce dengan mengurangi sampah dengan mengurangi pemakaian barang atau benda yang tidak terlalu kita butuhkan, Reuse dengan memakai dan memanfaatkan kembali barang-barang yang sudah tidak terpakai menjadi sesuatu yang baru. Recycle dengan mendaur ulang kembali barang lama menjadi barang baru.

3. Masyarakat desa Tongkok sudah dapat membuat dan mengolah sampah organik menjadi pupuk cair

\section{DAFTAR PUSTAKA}

Abdullah, Syahrial. 2015. Kajian Peningkatan Produktivitas Padi Sawah Melalui Pengelolaan Hara Spesifik Lokasi (Phsl) Pada Lahan Berpotensi Hasil Rendah: Jurnal Penelitian Pertanian Terapan Vol. 16 (1): 30-39 ISSN 14105020.

Ambarwati, Erlina dkk. 2011. Pengaruh Dosis dan Frekuensi Pemberian Pupuk Organik Cair Terhadap Pertumbuhan dan Hasil Buncis (Phasheolus vulgaris L.) Dataran Rendah. Jurnal Ilmu Pertanian. Vol.13 (2).

Cahyono, Bambang. 2013. Teknik Budidaya dan Analisis Usaha Tani Kacang Buncis. Yogyakarta : Kanisius.

Direktorat Jenderal Hortikultura Kementrian Pertanian. Laporan Tahunan 2018. Jakarta.

Djuariah, Diny. 2016. Budidaya Buncis. Jakarta : Badan Penelitian dan Pengembangan Pertanian.

Fajriah, A. C., G. Haryono, dan Historiawati. 2018. Respon Jumlah Tanaman per Lubang Terhadap Hasil Varietas Buncis (Phaseolus vulgaris, L.) Tipe Tegak. Jurnal Ilmu Pertanian Tropika dan Subtropika. 3(2) : 36-39.

Hadisuwito, S. 2012. Membuat Pupuk Kompos Cair. Jakarta: PT. Agromedia Pustaka. 


\section{JURNAL CEMERLANG: Pengabdian pada Masyarakat \\ P-ISSN 2654-4741 / E-ISSN 2655-7894 \\ Vol. 4, No. 1, Desember 2021, 76 - 87 \\ DOI: https://doi.org/10.31540/jpm.v4i1.1397 \\ PENERBIT: LP4MK STKIP PGRI LUBUKLINGGAU}

Handayani dkk. 2015. Lahan Paska Deforestasi di Bengkulu, Sumatera. Jurnal Ilmu-ilmu Pertanian Indonesia. Vol 4 (1)

Juarsah I. 2014. Pemanfaatan pupuk organik untuk pertanian organik dan lingkungan berkelanjutan. Makalah disajikan dalam Seminar Nasional Pertanian Organik Balai Penelitian Tanah. Bogor, 18-19 Juni.

Kementerian Pertanian. (2015). Kebijakan Teknis Program Pengembangan Usaha Agribisnis Pedesaan. Jakarta : Kementerian Pertanian

Listiyana. R. 2016. Pemanfaatan Daun Lamtoro dan Ekstrak Tauge dengan Penambahan Urine Sapi untuk Pembuatan Pupuk Organik Cair. Skripsi. Jurusan Biologi Fakultas Keguruan dan Ilmu Pendidikan Universitas Muhammadiyah, Surakarta.

Nur, dkk. 2016. Pembuatan Pupuk Organik Cair Dari Sampah Organik Rumah Tangga Dengan Penambahan Bioaktivator Em4 (Effective Microorganisms): Konversi Vol 5 (2): 2.

Parman, Sarjana. 2017. Pengaruh Pertumbuhan Pupuk Organik Cair Terhadap Pertumbuhan Tanaman Kentang (Solanum tuberosum L). Semarang: Laboratorium Biologi Struktur Dan Fungsi Tumbuhan Jurusan Biologi Fakultas FMIPA UNDIP.

Rihana, S., Y. B. S. Heddy dan M. D. Maghfoer. 2013. Pertumbuhan dan Hasil Tanaman Buncis (Phaseolus vulgaris L.) pada Berbabagai Dosis PupukKotoran Kambing dan Konsentrasi Zat Pengatur Tumbuh Dekamon. Produksi Tanaman, 1(4) : 369-377.

Sutanto, R. 2012. Pertanian Organik: Menuju Pertanian Alternatif dan Berkelanjutan. Yogyakarta: Kanisius.

Sitompul, S. M dan B. Guritno. 2014. Analisis pertumbuhan tanaman. Yogyakarta. Gadjah Mada University Press.

Yuwono, Teguh. 2014. Kecepatan Dekomposisi dan kualitas Kompos Sampah Organik: Jurnal Inovasi Pertanian. Vol. 4.(2). 